\title{
Seed yield of linseed varieties grown as 'paira' crop as influenced by dates of sowing
}

\author{
K. Jana ${ }^{1 \& 3^{*}}$, S. K. Das ${ }^{2 \& 3}$, D. C. Roy ${ }^{5}$, M. K. Kundu ${ }^{3}$, A. Kundu ${ }^{3}$ and G. Sathish ${ }^{4}$ \\ ${ }^{1}$ All India Coordinated Research Project (AICRP) on Forage Crops and Utilization, Directorate of Research, \\ Bidhan Chandra Krishi Viswavidyalaya, Kalyani, Nadia - 741235 (West Bengal), INDIA \\ ${ }^{2}$ AICRP on Potato, Directorate of Research, Bidhan Chandra Krishi Viswavidyalaya, Kalyani, Nadia- 741235 \\ (West Bengal), INDIA \\ ${ }^{3}$ Department of Agronomy, Faculty of Agriculture, Bidhan Chandra Krishi Viswavidyalaya, Mohanpur, Nadia - \\ 741252 (West Bengal), INDIA \\ ${ }^{4}$ Department of Agricultural Statistics, Faculty of Agriculture, Bidhan Chandra Krishi Viswavidyalaya, Mohanpur, \\ Nadia- 741252 (West Bengal), INDIA \\ ${ }^{5}$ Department of ILFC, WBUAFS, Mohanpur, Nadia -741252 (West Bengal), INDIA \\ *Corresponding author. E-mail: kjanarrs@gmail.com
}

Received: April 28, 2017; Revised received: July 20, 2017; Accepted: January 5, 2018

\begin{abstract}
Linseed is an industrial crop cultivated for its seeds, fibres and oil purpose. Linseed crop can met their requirement i.e. moisture and nutritional demand from stored soil moisture and residual fertility status in 'utera' or 'paira' system of cropping. On the basis of this fact an experiment was conducted on "Seed yield of linseed varieties grown as paira crop as influenced by dates of sowing" in red and laterite zone of West Bengal during rabi season of 2012-13 and 2013-14 at Rice Research Station, Bankura, West Bengal, India. Poor in organic matter content, available phosphate and bases, hard structure of iron and aluminium patterned as honeycomb are present in the subsurface regions of the profiles and kaolinite is the predominant clay minerals of red and lateritic zone (western part) of West Bengal. This experiment was laid out in a split-plot design with three replications and compared two factors (dates of sowing and linseed varieties). Objective was identifying the optimum date of sowing and suitable linseed varieties grown as 'paira' crop under changed climate in red and laterite zone of West Bengal. The experimental results revealed that the highest seed yield ( $534 \mathrm{~kg} \mathrm{ha}^{-1}$ as pooled value) was recorded from the treatment $D_{1}$ i.e. linseed sown on $15^{\text {th }}$ November. The lowest seed yield $\left(489.2 \mathrm{~kg} \mathrm{ha}^{-1}\right.$ as pooled value) was obtained with treatment $D_{3}$ i.e. linseed sown on $29^{\text {th }}$ November. Among linseed varieties, T-397 has yielded highest seed yield $\left(573.4 \mathrm{~kg} \mathrm{ha}^{-1}\right.$ as pooled value). Lowest seed yield (409. $3 \mathrm{~kg} \mathrm{ha}^{-1}$ as pooled data) was recorded from Neela variety. From the present study it may be concluded that linseed sown on $15^{\text {th }}$ November is the best time and T-397 is the suitable linseed variety grown as 'paira' crop under changed climate in red and laterite zone of West Bengal.
\end{abstract}

Keywords: Linseed, Paira crop, Sowing dates, Variety and Western zone of West Bengal

\section{INTRODUCTION}

Linseed (Linum usitatissimum L.) is world old crop and an ancient fibre crop. It is more commonly known as flax in western countries. It is an annual herbaceous plant belonging to lineaceae family, which is native to west Asia and the Mediterranean that has been cultivated since at least 5000 BC (Saghayesh et al., 2014). All parts of this plant have extensive and varied uses. It has an industrial value and is also used as proteinaceous feed for livestock as well as for human (Raundal et al., 2015). It is one of the most important cultivated plants concerning its high nutritional potential such as protein content, water-soluble fibre fraction, lignin content, mucilage, linamarin, enzymes (El-Nagdy et al., 2010) and today is mainly grown for its oil
(Oomah, 2001). It is a dual purpose crop for fibres and seeds. The long fibres are spun into linen yarns, moved into towelling, clothing fabrics and textiles. The short fibre are used for twins, paper manufacture and packing. It is an important oilseed cum fibre crop. Every part of the linseed plant is utilized commercially either directly or after processing. It is an important rabi oilseed crop in India and occupies 468 thousand ha area with productivity of $349 \mathrm{~kg} \mathrm{ha}^{-1}$ (DES, Agricultural Statistics at a Glance, Govt. of India, 2010). It is grown under rainfed (63\%), utrea $(20 \%)$ and irrigated (17\%) conditions (Rokade et al., 2015). It is grown both for its seed as well as fibre, which is used for the manufacture of linen. In addition, the oil obtained from seeds is considered an important source of essential poly unsaturated fatty acids (PUFA) in human diet. 
The seed contain about $30-40 \%$ fatty acids with easters of linoleic acid, linolenic acid, stearic acid and oleic acid that $\alpha$ - linolenic acid is the most important fatty acid in it (El-Nagdy et al., 2010). Its oil possesses a very healthy fatty acid profile, particularly Omega-3 (Alpha Linolenic Acid), which is richest source only in linseed (58\%). The beneficial effects are mostly due to flax lipids. Flax oil is the richest plant source of linoleic (omega-6) and linolenic (omega-3) poly unsaturated fatty acids (PUFA), which are essential fatty acids for human since they can not be synthesized in organism and must be obtained from food and has several human health benefits. Linolenic acid is major compound of PUFA. Delaying in sowing decreased the linoleic and linolenic acid content but increased the palmitic and oleic acids. For the best production and fatty acid contents, it is postulated that the sowing date offers a high economic yield and oil quality. Therefore, it is used as edible oil for human consumption and in some medical industries. ALA (Alpha Linolenic Acid) provides beneficial effects in numerous clinical conditions viz., immune function, cardiovascular disease and inflammatory disorders, cancer etc. [AICRP report on Oilseeds (linseed), College of Agriculture, Nagpur]. It is used in the treatment of symptoms of omega-3 fatty acids deficiency such as neurologic and visual disturbances, hemorrhagic dermatitis, folliculitis and growth retardation. Furthermore, it has anticancer effects on breast, prostate and colon cancers (Jhala and Hall, 2010). Its seed contain about 35-47 percent oil and 1132 percent protein (Raundal et al., 2015). It has quick drying property. So it is also used for the preparation of varnishes, paints, soap, oil cloth, printing ink and water proof fabrics. Straw from seed varieties is used in the manufacture of rugs, twine, upholstery rope and paper (Singh et al., 2008). The stem yields fibre of good quality having high strength and durability. The woody matter and short fibres are used as a raw pulp for making paper of quality. In addition, linseed meal is used as feed for livestock (Elayan sohair et al., 2015). Linseed is cool season crop and suited to tracts of low rainfall (Singh, 2009). In order to maximize the use of natural resources, the approximate sowing date is very important since it ensure good seed germination as well as the timely appearance of seedling and the optimum development of the root system. It also allows superposing the critical periods for seed yield and its components with the moment of the growth season where more environmental resources are available (Balalic et al., 2012). Therefore, attempts have been devoted to maximize linseed productivity per unit area by growing high yielding varieties as 'paira' or by improving agronomic practices such as sowing date under changed climate in red and laterite zone of West Bengal, India.

\section{MATERIALS AND METHODS}

'Utera' or 'Paira' crop may be defined as the crop which is taken with another crop in the same piece of land. When the first crop is at flowering stage, then the seeds of 'paira' crop are broadcasted on the same land. There is no need for land preparation for 'paira' or 'utera' crop. Linseed crop can be included in the 'utera' or 'paira' cropping system after rice crop of kahrif season. It can meet their requirement from stored soil moisture and residual fertility in the soil under 'utera' or 'paira' system of cropping. On the basis of this fact, an experiment was conducted on "Seed yield of linseed varieties grown as paira crop as influenced by dates of sowing" in red and laterite zone of West Bengal during rabi season of 2012-13 and 2013-14 at Rice Research Station, Bankura, West Bengal, India. This experiment was laid out in a split-plot design with three replications and compared two factors (dates of sowing and linseed varieties) to identify optimum date of sowing with special reference to changed climate and suitable linseed varieties grown as 'paira' crop regarding yield potentiality in red and laterite zone of West Bengal. Three levels of dates of sowing $\left(D_{1}=15^{\text {th }}\right.$ November, $D_{2}=22^{\text {nd }}$ November, $D_{3}$ $=29^{\text {th }}$ November] were randomly allotted in the three main plots; while four linseed varieties $\left(\mathrm{V}_{1}=\mathrm{T}-397\right.$, $\mathrm{V}_{2}=\mathrm{LW}-92-870, \mathrm{~V}_{3}=$ Parvati and $\mathrm{V}_{4}=$ Neela) were randomly allotted in the four sub plots of each main plot. Seven days of time interval is selected in between two date of sowing to avail the sufficient moisture level for germination of linseed seed in the kharif paddy field in paira system of cropping under changed climate.

The experimental site represents low rainfall area (drought prone) of the West Bengal state with average annual rainfall of 1200-1400 $\mathrm{mm}$. The upland soils are mostly eroded with a very low water holding capacity. Crust formation in the upland soils is serious problem. This experiment was conducted in upland. Physicochemical properties of the experimental soil up to the depth of $15 \mathrm{~cm}$ were studied following Jackson (1973) to know the initial status before conducting the experiment. The texture of experimental soil was sandy loam with slightly acidic in nature ( $\mathrm{pH}: 5.4), 0.13 \mathrm{ds} \mathrm{m}^{-1} \mathrm{EC}$, organic carbon $0.43 \%$, available $\mathrm{P}_{2} \mathrm{O}_{5} 51 \mathrm{~kg} \mathrm{ha}^{-1}$ and available $\mathrm{K}_{2} \mathrm{O} 162 \mathrm{~kg} \mathrm{ha}^{-1}$. The soil of experimental field was medium in fertility status. The plot size was $4 \mathrm{~m} \times 3 \mathrm{~m}$. No fertilizers were applied as basal and split doses in this experiment. Only $2 \%$ urea was applied as foliar spray at 45 days after sowing (DAS) to obtain better seed yield and linseed varieties in this experiment were grown mainly by utilizing the stored soil moisture and residual fertility in the soil after harvesting of paddy crop of kharif season. One and two light irrigations were applied during flowering and seed development stages, respectively as the critical growth 
stages for water of this crop to obtained good seed yield. Statistical analyses of data were carried out by using MSTAT and critical differences at 5\% level of significance were calculated following Fisher (1937) and Panse and Sukhatme (1967).

\section{RESULTS AND DISCUSSION}

Number of capsule per plant: It is an important yield contributing character of linseed crop. The results of experimentation revealed that the levels of dates of sowing significantly influenced the number of capsule per plant at 5\% level of significance. The highest number of capsule plant ${ }^{-1}$ was 39,41 and 40 during both years of experiment and pooled value, respectively obtained from the treatment $\mathrm{D}_{1}$ i.e. $15^{\text {th }}$ November sown crop. It was statistically at par with the treatment $\mathrm{D}_{2}$ i.e. $22^{\text {nd }}$ November sown crop, where number of capsule plant ${ }^{-1}$ was $34.5,37.1$ and 35.8 during $1^{\text {st }}, 2^{\text {nd }}$ year and pooled value, respectively. This might be associated with linseed sown in $15^{\text {th }}$ November was exposed to low temperature, more dew formation, higher coldness and resulted in higher growth characteristics, like plant height and number of capsule per plant. The results are in the conformity with those of Abdul EL-Dayem et al. (1998). The lowest number of capsule plant ${ }^{-1}$ was $27.7,30.4$ and 29 during both years of experiment and pooled value, respectively recorded with the treatment $\mathrm{D}_{3}$ i.e. $29^{\text {th }}$ November sown crop (Table 1). It was significantly lower than other treatments at 5\% level of significance. The lower capsule numbers observed with later flowering may be due to a temperature effect on pollination and ovary survival in delayed sowing dates (Mirshekari et al., $2012 b$ ). The results are in conformity with the findings of Shaikh et al., (2009) and they reported that sowing date has significant effect on some growth characteristics and yield attributes of linseed. This might be due to different sowing dates expose the linseed crop to

Table 1. Seed yield and ancillary characters of linseed varieties grown as 'paira' as influenced by dates of sowing during rabi season of 2012-2013 and 2013-2014.

\begin{tabular}{|c|c|c|c|c|c|c|c|c|c|}
\hline \multirow{2}{*}{ Treatments } & \multicolumn{3}{|c|}{ No. of capsules per plant } & \multicolumn{3}{|c|}{ 1000-seed weight $(\mathrm{g})$} & \multicolumn{3}{|c|}{ Seed yield $\left(\mathrm{Kg} \mathrm{ha}^{-1}\right)$} \\
\hline & $1^{\text {st }}$ Yr. & $2^{\text {nd }} Y r$. & Pooled & $1^{\text {st }}$ Yr. & $2^{\text {nd }} Y r$. & Pooled & $1^{\text {st }} \mathbf{Y r}$. & $2^{\text {nd }} Y r$. & Pooled \\
\hline \multicolumn{10}{|c|}{ Levels of dates of sowing } \\
\hline $\mathrm{D}_{1}\left(15^{\text {th }}\right.$ November $)$ & 39.0 & 41.0 & 40.0 & 5.08 & 4.98 & 5.03 & 531.7 & 536.4 & 534.0 \\
\hline $\mathrm{D}_{2}\left(22^{\text {nd }}\right.$ November $)$ & 34.5 & 37.1 & 35.8 & 5.01 & 4.90 & 4.95 & 516.1 & 520.9 & 518.5 \\
\hline $\mathrm{D}_{3}\left(29^{\text {th }}\right.$ November $)$ & 27.7 & 30.4 & 29.0 & 4.91 & 4.88 & 4.89 & 486.3 & 492.1 & 489.2 \\
\hline $\operatorname{S.Em}( \pm)$ & 1.18 & 1.34 & 1.13 & 0.31 & 0.35 & 0.32 & 8.46 & 8.67 & 8.32 \\
\hline $\mathrm{CD}(\mathrm{P}=0.05)$ & 4.65 & 5.01 & 4.21 & NS & NS & NS & 25.22 & 25.82 & 25.02 \\
\hline \multicolumn{10}{|l|}{ Linseed varieties } \\
\hline $\mathrm{V}_{1}-\mathrm{T} 397$ & 42.1 & 45.0 & 43.5 & 5.15 & 5.10 & 5.12 & 571.2 & 575.6 & 573.4 \\
\hline$V_{2}-L W-92-870$ & 32.1 & 34.5 & 33.3 & 4.91 & 4.76 & 4.83 & 507.8 & 512.9 & 510.3 \\
\hline $\mathrm{V}_{3}$ - Parvati & 36.9 & 39.8 & 38.3 & 5.04 & 5.02 & 5.03 & 560.2 & 564.8 & 562.5 \\
\hline $\mathrm{V}_{4}-$ Neela & 23.9 & 25.4 & 24.6 & 4.89 & 4.80 & 4.84 & 406.1 & 412.5 & 409.3 \\
\hline S.Em $( \pm)$ & 4.94 & 4.52 & 4.64 & 0.38 & 0.41 & 0.39 & 15.31 & 15.68 & 15.12 \\
\hline $\mathrm{CD}(\mathrm{P}=0.05)$ & 14.6 & 13.2 & 14.1 & NS & NS & NS & 45.50 & 46.05 & 45.21 \\
\hline
\end{tabular}

Table 2. Interaction effects between dates of sowing and linseed varieties grown as 'paira' on seed yield and ancillary characters during rabi season of 2012-2013 and 2013-2014.

\begin{tabular}{|c|c|c|c|c|c|c|c|c|c|c|}
\hline \multirow{2}{*}{$\begin{array}{l}\text { Levels of dates } \\
\text { of sowing (D) }\end{array}$} & \multirow{2}{*}{$\begin{array}{l}\text { Linseed } \\
\text { varieties (V) }\end{array}$} & \multicolumn{3}{|c|}{ No. of capsules per plant } & \multicolumn{3}{|c|}{ 1000-seed wt. (g) } & \multicolumn{3}{|c|}{ Seed yield $\left(\mathrm{Kg} \mathrm{ha}^{-1}\right)$} \\
\hline & & $1^{\text {st }}$ Yr. & $2^{\text {nd }} Y r$. & Pooled & $1^{\text {st }}$ Yr. & $2^{\text {nd }} Y r$. & Pooled & $1^{\text {st }}$ Yr. & $2^{\text {nd }}$ Yr. & Pooled \\
\hline \multirow{4}{*}{$\mathrm{D}_{1}$} & $\mathrm{~V}_{1}$ & 48.5 & 51.2 & 49.8 & 5.25 & 5.12 & 5.18 & 592.6 & 596.4 & 594.5 \\
\hline & $\mathrm{V}_{2}$ & 37.1 & 38.5 & 37.8 & 5.03 & 4.89 & 4.96 & 528.3 & 532.1 & 530.2 \\
\hline & $\mathrm{V}_{3}$ & 43.4 & 45.6 & 44.5 & 5.15 & 5.18 & 5.16 & 580.2 & 584.8 & 582.5 \\
\hline & $\mathrm{V}_{4}$ & 27.3 & 28.7 & 28.0 & 4.89 & 4.75 & 4.82 & 425.7 & 432.5 & 429.1 \\
\hline \multirow[t]{4}{*}{$\mathrm{D}_{2}$} & $\mathrm{~V}_{1}$ & 43.6 & 46.4 & 45.0 & 5.13 & 5.16 & 5.14 & 575.8 & 578.3 & 577.0 \\
\hline & $\mathrm{V}_{2}$ & 32.5 & 35.3 & 33.9 & 4.87 & 4.56 & 4.71 & 512.7 & 517.6 & 515.1 \\
\hline & $\mathrm{V}_{3}$ & 37.3 & 39.5 & 38.4 & 5.05 & 5.01 & 5.03 & 568.4 & 572.2 & 570.3 \\
\hline & $\mathrm{V}_{4}$ & 24.6 & 27.2 & 25.9 & 4.97 & 4.87 & 4.92 & 407.5 & 415.7 & 411.6 \\
\hline \multirow[t]{4}{*}{$\mathrm{D}_{3}$} & $V_{1}$ & 34.3 & 37.5 & 35.9 & 5.08 & 5.02 & 5.05 & 545.3 & 552.3 & 548.8 \\
\hline & $\mathrm{V}_{2}$ & 26.7 & 29.7 & 28.2 & 4.82 & 4.85 & 4.83 & 482.6 & 489.2 & 485.9 \\
\hline & $\mathrm{V}_{3}$ & 30.2 & 34.3 & 32.2 & 4.92 & 4.89 & 4.90 & 532.1 & 537.4 & 534.7 \\
\hline & $\mathrm{V}_{4}$ & 19.8 & 20.4 & 20.1 & 4.80 & 4.78 & 4.79 & 385.3 & 389.5 & 387.4 \\
\hline \multicolumn{11}{|l|}{ D at same V } \\
\hline \multicolumn{2}{|l|}{$\operatorname{S.Em}( \pm)$} & 8.5 & 7.8 & 7.2 & 0.66 & 0.69 & 0.67 & 26.52 & 25.63 & 24.23 \\
\hline \multirow{2}{*}{\multicolumn{2}{|c|}{$\begin{array}{l}\mathrm{CD}(\mathrm{P}=0.05) \\
\mathrm{V} \text { at same of different } \mathrm{D}\end{array}$}} & 25.4 & 23.5 & 22.4 & NS & NS & NS & 78.81 & 75.09 & 74.14 \\
\hline & & & & & & & & & & \\
\hline \multicolumn{2}{|c|}{ S.Em $( \pm)$} & 7.51 & 8.2 & 7.24 & 0.65 & 0.68 & 0.67 & 24.48 & 23.58 & 22.47 \\
\hline \multicolumn{2}{|l|}{$\mathrm{CD}(\mathrm{P}=0.05)$} & 22.4 & 24.9 & 22.1 & NS & NS & NS & 75.53 & 73.52 & 74.16 \\
\hline
\end{tabular}




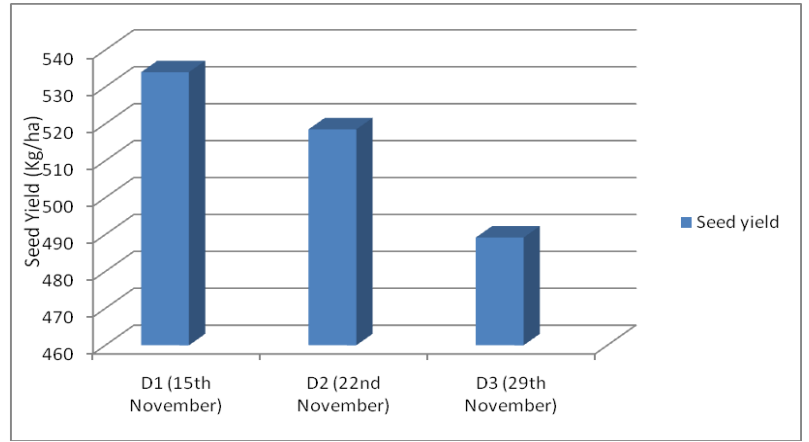

Fig. 1. Seed yield of linseed as influenced by different dates of sowing.

climatic condition hence, obstruction in seed filling in capsule of linseed varieties and adversely reflects it in number of seed per capsule. This result is in agreement with the findings of Dixit et al. (1992) and Abdul ElDayem et al. (1998).

From the experimental results (Table 1) it was revealed that the levels of linseed varieties significantly influenced the number of capsule plant ${ }^{-1}$ at $5 \%$ level of significance. The highest number of capsule plant ${ }^{-1}$ (42.1, 45 and 43.5 during both years of experiment and pooled value, respectively) was obtained from the treatment $\mathrm{V}_{1}$ i.e. $\mathrm{T}-397$ linseed variety. It was statistically at par with the treatment $\mathrm{V}_{3}$ i.e. Parvati, which recorded 36.9, 39.8 and 38.3 capsules plant ${ }^{-1}$ during $1^{\text {st }}$, $2^{\text {nd }}$ year and pooled value, respectively. The interaction between dates of sowing and linseed varieties significantly influenced the number of capsules per plant in both seasons and pooled value (Table 2).

Test weight: From the results of experimentation it was revealed that the test weight i.e. 1000-seed weight was not significantly influenced by the dates of sowing and linseed varieties in both the years and pooled value (Table 1 and 2). The result is in agreement with the findings of Farhadi et al. (2013) and they reported that sowing dates had no significant effect on test weight.

Seed yield (Kg ha $\left.{ }^{-1}\right)$ : It was revealed from the experimental results that the levels of date of sowing significantly influenced the seed yield at 5\% level of significance. The highest seed yield was 531.7, 536.4 and $534.0 \mathrm{~kg} \mathrm{ha}^{-1}$ during rabi season of 2012-13 and 201314 of experimentation and pooled value, respectively recorded from the treatment $\mathrm{D}_{1}$ i.e. $15^{\text {th }}$ November sown crop. It was statistically at par with the treatment $\mathrm{D}_{2}$ i.e. $22^{\text {nd }}$ November sown crop, where seed yield was $516.1,520.9$ and $518.5 \mathrm{~kg} \mathrm{ha}^{-1}$ during $1^{\text {st }}, 2^{\text {nd }}$ year and pooled value, respectively. This might be due to sowing date on $15^{\text {th }}$ November was favourable to high seed production because the post anthesis period coincide with the relatively low temperature. The lowest seed yield was $486.3,492.1$ and $489.2 \mathrm{~kg} \mathrm{ha}^{-1}$ during both years of experiment and pooled value, respectively recorded with the treatment $\mathrm{D}_{3}$ i.e. $29^{\text {th }}$ November sown crop (Table 1 and Fig. 1). The seed yield ob-

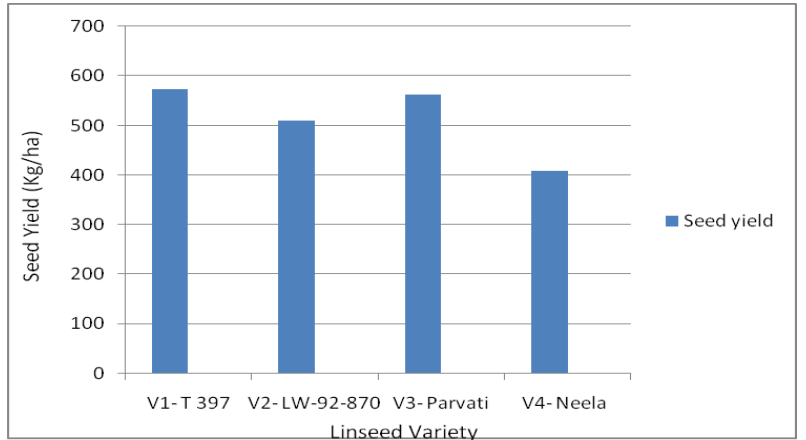

Fig. 2. Seed yield of linseed as influenced by different varieties.

tained with $29^{\text {th }}$ November sown crop was lower than other treatments of sowing dates. It was significantly lower than other treatments at 5\% level of significance. However, late sowing date was unfavourable to seed yield. The results are in conformity with the findings by Kalita et al. (1999). Moreover, sowing of flax/ linseed on the $15^{\text {th }}$ November suppressed these sown on $29^{\text {th }}$ November in seed yield per ha. The increase in seed yield ha ${ }^{-1}$ due to sown on the $15^{\text {th }}$ November may be attributed to increase in number of fruiting branches per plant which reflected increases in capsules number as well as seed number per unit area and that in turn reflected increases in seed yield per ha. The inferiority of delaying sowing to last November may be attributed to the short period of vegetative growth and the adverse weather conditions such as temperature, which were beyond the optimum degree for vegetative and reproductive stages that resulted in low photosynthetic products accumulated in the source (leaves) and transplanted to the sink (seeds) (Al-Doori, Saad A.; 2012). This might be due to impact of changed climate on crop production is expected for various latitude limits for all the crop seasons and the linseed crop is most affected during winter season. Linseed crop require cool climate and moderate temperature (not exceeds above $32^{\circ} \mathrm{C}$ ). Increase in temperature affects on flowering and causes low yield. Amongst various agronomic practices, the time of sowing plays an important role in influencing the quality and yield of linseed. Normal sowing have longer growth period which consequently provide an opportunity to accumulate more biomass as compared to late sowing hence manifested in higher seed and biological yield (Dixit et al., 1992). Sowing date had no significant effect on seed weight, but it had significant effect on seed yield. It was maximum in first sowing date and decreased with delaying sowing in agreement with the findings of Farhadi et al. (2013) which may be due to a high temperature effect on pollination and seed development and long photo period that exist during capsules development. High temperatures during the period of reproductive growth lead to decline of reproductive growth period, failure in the number of crops and finally decreased the number of 
seeds and then the decline comes to seed yield (Aldoori, 2012). Ghanem, 1990 reported that increases of seed yield due to increases of dry matter accumulation in the later formed capsules may be attributed to high temperature and long photoperiod that exist during capsules development. The increase in seed yield per ha due to sowing on $15^{\text {th }}$ November may be due to the increase in number of branches per plant and number of capsules per plant which reflects in higher seed yield. Similar conclusions were reported by El-Refaey et al., 2010. As sowing dates affected significantly the productivity and seed yield as reported by EL-Deep and Abd EL-Fatah, 2006. They reported that sowing linseed on $15^{\text {th }}$ November recorded the mean of straw and seed yields as well as its components. The results are in conformity with the findings of Shaikh et al., (2009) and they reported that sowing date has significant effect on seed yield, oil and protein contents of linseed.

It was revealed from the experimental results that among different linseed varieties, T-397 has yielded highest seed yield of 571.2, 575.6 and $573.4 \mathrm{~kg} \mathrm{ha}^{-1}$ during rabi season of 2012-13, 2013-14 and pooled value, respectively. It was statistically at par with the seed yield obtained from Parvati (560.2, 564.8 and $562.5 \mathrm{~kg} \mathrm{ha}^{-1}$ ) during both years of experimentation and pooled value, respectively under 'paira' system of cropping and it was statistically significant than other varieties at 5\% level of significance (Table 1 and Fig. 2). The lowest seed yield (406.1, 412.5 and $409.3 \mathrm{~kg}$ $\mathrm{ha}^{-1}$ during rabi season of 2012-13, 2013-14 and pooled value, respectively) was recorded from linseed variety Neela. It was significantly lower than other linseed varieties at $5 \%$ level of significance. The results in Table 1 and 2 indicated that linseed varieties significantly differed in number of capsules per plant and seed yield per ha in both the years and pooled value. The differences between linseed varieties in seed yield per ha might be attributed to their differences in growth traits such as number of fruiting branches reflected differences in yield components such as number of capsule per plant as well as 1000 -seed weight and hence increased seed yield per plant as well as per unit area. The results are in agreement with the findings of El-Shimy et al. (2001), El-Shimy et al. (2002), Dimmock et al. (2005) and Hussein (2007) and they observed that flax genotypes significantly differed in number of capsules per plant and finally seed yield per hectare.

Among the four linseed varieties, T-397 exerted first promising yield attributing characters (mainly capsule per plant) during investigation, which reflected in seed yield. The climatic condition and genetic makeup of variety had better interaction, which could be enhanced growth and development of capsules. The increased in seed yield by the linseed varieties, like T-397 mainly due to overall respective performance in growth and appreciable improvement in the yield attributing characters. Productivity of crop is collectively determined by vegetative growth coupled with higher yield attributes resulting in higher seed yield. Significant variations in seed yield of linseed varieties as 'paira' crop in western part of West Bengal have also been reported by Jana et al. (2013) and they reported that T-397 and Parvati performed better as 'paira' or 'utera' crop after harvesting of paddy in red and laterite zone of West Bengal. The interaction between dates of sowing and linseed varieties had a significant effect on seed yield in both years of experiment and pooled value (Table 2). The results indicated that linseed variety $\mathrm{T}$ 397 gave the highest seed yield of $594.5 \mathrm{~kg} \mathrm{ha}^{-1}$, when sown on $15^{\text {th }}$ November.

Incidence of pests: No pests and diseases were observed during both years of this experimentation in the research field. The result is in agreement with findings of Singh and Singh (2004) and they reported that linseed crop sown on $5^{\text {th }}$ November gave highest yield and less disease intensity. The most widely cited insect of this crop are cutworms, grasshoppers, aster leaf hopper and aphids (Saha, 2003). The serious diseases of flax are fusarium wilt (Fusarium oxysporum f. Sp. lini) and linseed rust (Melampsora lini). Most can be reduced or controlled by using resistant varieties, cultural practices and careful use of crop rotation (Anonymous, 2008).

\section{Conclusion}

This 'utera' or 'paira' system of cropping of linseed is most important approach for saving water, fertilizer and labour etc. View extrapolated from the results of this experiment that linseed crop can be successfully grown in 'paira' system of cropping. 'Paira' cropping of linseed crop is much beneficial for the farmers of West Bengal, particularly in red and laterite zone of the state and it can be grown without manuring the field. Linseed variety T-397 has yielded highest seed yield of $573.4 \mathrm{~kg} \mathrm{ha}^{-1}$ (pooled value) during rabi season. The highest seed yield was $534.0 \mathrm{~kg} \mathrm{ha}^{-1}$ during rabi season (pooled value) recorded from the $15^{\text {th }}$ November sown crop. The T-397 variety has recorded excellent performance and contributed to maximum seed yield in 'paira' cropping system, when sown on $15^{\text {th }}$ November under changed climate. Performance of parvati variety was also better under red and laterite zone of West Bengal, India. In summary, it is concluded that sowing date was a very important management tool in minimizing the negative impact of high temperature during critical flowering and seed filling periods. From the present study it may be concluded that sowing of linseed cv. T 397 with $15^{\text {th }}$ November was found advantageous in recording more seed yield. Thus, it can be concluded that the date of $15^{\text {th }}$ November was found superior for growth, yield attributes and seed yield of linseed. The linseed variety T 397 was 
suitable for 'piara' or 'utera' system of cropping with regards to growth, yield attribute and seed yield. The results of the present study may be helpful for recommendation of optimum sowing date for linseed production in similar climatic condition.

\section{ACKNOWLEDGEMENTS}

The authors would like to thanks Dr. P. K. Maity, Chief Agronomist, FCRS, Burdwan; Dr. S. R. Patra, Joint Director of Agriculture (Research) and Dr. P. Bhattacharya, Director of Agriculture, Department of Agriculture, Govt. of West Bengal, Writers' Buildings, Kolkata - 700 001, West Bengal, India for their valuable guidance and encouragement during the period of this research programme.

\section{REFERENCES}

Abdul El-Dayem, M.A., Shams, S.A.A. and AbdoKaied, H.M.H. (1998), Effect of plantimg dates and seeding rates on yield and its components of flax (Linumusitatissimum L.) grownunder newly reclaimed land. Annals.Agric.Sci.Moshtohar. 40(2):741-749

AICRP report on Oilseeds (Linseed), Principal Scientist and Linseed Breeder. College of Agriculture, Nagpur.

Al-Doori, Saad A. (2012) influence of sowing date on growth, yield and quality of some flax genotypes. College of Basic Education Research Journal, 12(1):733744

Anonymous (2008). Oilseed crop, Flax. Oregon State University, U.S. Department of Agriculture.

Balalic, I., Zoric, M., Brankovic, G., Terzic, S., and Crnobarac, J. (2012). Interpretation of hybrid x sowing date interaction for oil contents and oil yield in sunflower. Field Crops Res. 137: 70-77.

Dimmock, J.P.R.E., S.J. Bennett, D. Wright, G Edwards Jones and I.M. Harris. (2005). Agronomic evaluation and performance of flax varieties for industrial fibre production J. of Agric. Sci. 143:299-309.

DES (2010). Directorate of Economics and Statistics, Agricultural Statistics at a Glance, Department of Agricultural and cooperation. Ministry of Agriculture, Government of India, 2010.

Dixit, J. P., Chourasia, S. K., Pillani, P. V. A. and Khan, R. A. (1992). Assessment of linseed (Linum usitatissium L.) varieties under double-cropping system in Tawa command. Indian J. Agron., 39 (1): 105-109.

Elayan sohair, E.D., Amany A, M., Nemat, A. N. and Doaa M, I. (2015). Effect of sowing date on yield, fibre and seed quality of eight flex genotypes, American- Eurasian J. Agric. \& Environ. Sci., 15 (5): 886-895.

El-Nagdy, G. A., Nassar, D. M. A., El-Kady, E. A. and ElYamanee G. S. A. (2010). Response of flax plant (Linum usitatissium L.) to treatments with mineral and bio-fertilizers from nitrogen and phosphorus. J. Amer. Sci., 6 (10): 207-217.

El-Refaey, R.A., E. H. El-Seidy and I.A.E., El-Deeb. (2010). Effect of sowing dates under different environment condition on yield and quality of some flex genotypes. Alex. J. Agric. Res., 55 (2): 33-41.

El-shimy, G. H., S.H.A. Mostafa and M.A. Abd El-Dayem. (2002). Effect of NPK fertilizer levels on yield and its components of some flax genotypes. Ann. Agric. Sci. Moshtohor, 40 (1): 6779.

El-Shimy, G.M.; S.H.A. Mostafa and E.A. Moawed. (2001). Effect of mineral and biophosphorus fertilization on productivity and quality of Sakha I and Giza 8 flax varieties. Egypt. J. Apple. Sci., 16 (8): 101-117.

Farhadi, N., Souri, M. K., Alirezalu, A. and Moghaddam, M. (2013). Effects of sowing dates on quantity and quality of castor bean (Ricinus communis L.) under semi-arid condition in Iran. $Z$ Arznei-Gewurzpfla., 18 (2): $72-77$.

Fisher, R. A. (1937). Statistical method for research workers. Oliver and Boyd and Co. Ins Endinburgh.

El-Deep, E.E.A. and A. A. Abd El-Fatah. (2006). Effect of sowing and harvesting dates on yield and its quality for some flax varieties. J Agric. Sci. Mansoura univ., 31 (9): $5557-5566$

Ghanem, S.A. I. (1990). The influence of $\mathrm{N}$ fertilization and sowing, harvesting dates on oil, fibre yields and their contributing characters of flax. Zagazig. J. Agric. Res. 17 (3): 575-587.

Hussein, M.M.M. (2007). Response of some flax genotypes to bio and nitrogen fertilization Zagazig. J. Agric. Res., 34(5): 815-844.

Jackson, ML. (1973). Soil Chemical Analysis. New Delhi, Prentice Hall of India Private Limited, New Delhi: 326338

Jana, K., Mallick, G. K. and Ghosh, S. (2013). Performance of different linseed varieties in 'paira' cropping system. Crop Research, 46 (1, 2 \& 3): 119-121.

Jhala, A. J. and Hall, L. M. (2010). Flax (Linum usitatissium L.): Current uses and future applications. Aust. J. Basic Appl. Sci., 4 (9): 4304-4312.

Kalita, H., Bora, P. C. and Debnath, M. C. (1999). Effect of sowing dates and tillage on the soil properties, nutrient uptake and yield of linseed (Linum usitatissium L.) grown in winter rice (Oryza sativa). India J. Agron., 50 (1): 70-72.

Mirshekari, M., Amiri, R., Iran Nezhad, H., Sadat Noori, S. A. and Zand Vakili O. R. (2012b). Effects of palnting date and water deficit on quantative and qualitative traits of flax seed. Am. Eur. J. Agric. Environ. Sci., 12: 901913

Oomah, B. D. (2001). Flax seed as a functional food source. J. Sci. Food Agr., 81: 889-894.

Panse, V.G. and Sukhatme, P.V. (1967). Statistical methods for agricultural workers. ( $1^{\text {st }}$ Ed.) ICAR, New Delhi, India.

Raundal, P. V., Pohare, V. B. and Shinde, L. D. (2015). Response of different linseed varieties under extended sowing dates. Int. J. Tropical Agric., 33 (4): 3485-3488.

Rokade, B.S., Madane, K. T., Jadhav, J. D. and Kamble, P.S. (2015). Linseed sowing dates, genotypes influence on growth, yield attributes and yield. International Journal of Agricultural Sciences, 11. (2): 248-256.

Saghayesh, S. P., Moghaddam, M. and Mehdizadeh, L. (2014). Effect of sowing dates on the morphological characteristics, oil yield and composition of fatty acids in flax (Linum usitatissium L.). Int. J. Agri. Crop. Sci., 7 (11): 915-922.

Saha, L.R. (2003). Flax - Oilseed crops. Handbook of Plant Protection published by Kalyani Publishers, Noida: 275 -278 . 
Shaikh, F. G., Gokhale, D. N., Rokade, B. S. and Jadhav, P. J. (2009). Effect of sowing date on some growth characters in linseed. J. Agrometeorolo, 11 (2): 203-205.

Singh, C., Singh, P. and Singh, R. (2008). Linseed. Modern Techniques of Raising Field Crops published by Oxford \& IBH Publishing CO. PVT. LTD., New Delhi: $355-$ 362.
Singh, N., Palat, R., Dabbas, M. R. and Chandra, D. R. (2008). Effect of date of sowing on yield and disease intensity of Alternaria blight in linseed. Int. J. Plant Protection, 1 (2): 38-39.

Singh, S.S. (2009). Linseed, Oilseeds-Production Constraints \& Strategies. Crop Management published by Kalyani Publishers, Noida: 258-259. 